\title{
Standardization of Seed Rate for Mechanical Sowing of Newly Released Varieties of Chickpea
}

\author{
P. Sujathamma* and D. Venkatesh Babu \\ Agricultural Research Station, Podalakur-524345, Andhra Pradesh, India \\ *Corresponding author
}

Keywords

Chickpea, Seed rate, Varieties, Mechanical Sowing

Article Info

Accepted:

15 January 2019

Available Online:

10 February 2019
A B S T R A C T

A field experiment was conducted at Seed Technology Research and Production Centre, Thangedancha during rabi 2017-18 to standardize seed rate for mechanical sowing of newly released varieties of chickpea. In this investigation, growth, yield parameters and yield of chickpea were significantly influenced by the varieties, seed rates and their interaction. Among the three varieties Nandyala gram 49 recoded significantly the highest number of pods per plant, 100 grain weight and grain yield but which was statistically on par with Nandayala Senaga-1 in grain 100 grain weight and grain yield. Among the three seed rates $150 \%$ recommended seed rate recorded the highest grain yield, but which was statistically on par with $125 \%$ recommended seed rate. Nandyala gram- 49 and Nandyala senaga-1 recorded the highest seed yield at $125 \%$ recommended seed rate. Dheera recorded the highest seed yield at $150 \%$ recommended seed rate. The higher net returns were recorded with Nandyala gram 49 at $125 \%$ recommended seed rate.

\section{Introduction}

Chickpea (Cicer arietinum L.) is the most important rabi pulse crop. It accounts for more than one third of the area and about $50 \%$ of the production of pulses in India. In India it is grown in an area of 9.93 million hectares with a total production of 9.88 million tonnes with an average productivity of $937 \mathrm{~kg} \mathrm{ha}^{-1}$. Andhra Pradesh, Madhya Pradesh, Uttar Pradesh, Rajasthan, Maharastra, Gujarat and Karnataka are the major chickpea producing states sharing over $95 \%$ area. In Andhra Pradesh it is grown over an area of 1.28 million hectares with an annual production of 1.09 million tonnes and an average productivity of $849 \mathrm{~kg} \mathrm{ha}^{-1}$ (Annual Report, 2016-17, DAC\&FW).

Yield of chickpea is mainly influenced by varieties and management practices. Among the agronomic practices, proper seed rate is of great importance (Reddy et al., 2003). Now a days seeding with 8 row seed cum fertilizer drill is common in chickpea to decrease the sowing time and labour as well as for ensuring proper depth of placement and seeds get covered with soil. Recommended seeding rates for mechanical sowing differ based on cultivar and seed size. Development of new high yielding cultivars is continuous process. Various cultivars behave differently due to 
difference in their plant architecture. A positive relationship between seeding rate (and subsequent plant density) and yield has been documented by several studies (Silim and Saxena 1991; Jettner et al., 1999; Gan et al., 2003; Regan et al., 2003). Keeping this view an experiment was conducted with an objective to standardize the seed rate for mechanical sowing of newly released cultivars of chickpea.

\section{Materials and Methods}

The experiment was conducted during rabi season of 2017-18 at Seed Technology Research and Production Centre, Thangedancha under rainfed conditions. The experimental site is situated in the $15^{\circ} 88$ latitude $78^{0} 37^{\prime}$ E longitude and at an altitude of 281 meters above mean sea level. The experimental field was clayey in texture and grouped under vertisols, with alkaline in soil reaction ( $\mathrm{pH} \mathrm{8.4),} \mathrm{medium} \mathrm{in} \mathrm{organic} \mathrm{carbon}$ (0.58) (Walkley and Black, 1934), low in available nitrogen (188 kg ha- ${ }^{1}$ ) (Subbaiah and Asija, 1956), high in phosphorous (42.6kg ha ${ }^{-1}$ ) (Jackson, 1967) and potassium (527 kg ha-1) (Muhr et al., 1965).

The field experiment was laid out in split plot design with three replications. The treatments comprised three varieties of chickpea viz., Nandyal Senaga-1 $\left(\mathrm{V}_{1}\right)$, Dheera $\left(\mathrm{V}_{2}\right)$ and Nandyala gram $49\left(\mathrm{~V}_{3}\right)$ as main plots and three seed rates viz., $100 \%$ Rec. seed rate i.e., $100 \mathrm{~kg} \mathrm{ha}{ }^{-1}\left(\mathrm{~S}_{1}\right)(30 \times 10 \mathrm{~cm}), 125 \%$ Rec. seed rate i.e., $125 \mathrm{~kg} \mathrm{ha}^{-1}\left(\mathrm{~S}_{2}\right)(30 \times 7.5 \mathrm{~cm})$ and $150 \%$ Rec. seed rate i.e., $150 \mathrm{~kg} \mathrm{ha}^{-1}\left(\mathrm{~S}_{3}\right)$ $(30 \times 5.0 \mathrm{~cm})$ as sub plots. Crop was sown on 07-12-2018 with tractor drawn seed drill. $20 \mathrm{~kg}$ nitrogen and $50 \mathrm{~kg}$ phosphorus fertilizers were applied as basal. Nitrogen and phosphorus fertilizers were applied in the form of Urea and Single Super Phosphate. The crop was grown under residual soil moisture conditions. All the recommended practices were followed. Standard procedures were followed to collect the data and analysed by using Fishers analysis of variance techniques and the least significant difference at $5 \%$ probability level was used to compare the treatment means (Fisher, 1950).

\section{Results and Discussion}

\section{Performance of chickpea varieties}

A cursory glance on the data presented in Table 1 indicates that among the three varieties of chickpea, Dheera recorded significantly the highest plant height $(38.5 \mathrm{~cm})$. Chickpea varieties differed significantly with each other in respect of yield attributing characters and yield. Nandyala gram 49 recoded significantly higher number of pods per plant and 100 grain weight, but it was statistically on par with NandayalaSenaga1 in 100 grain weight. Higher attributing parameters in chickpea variety Nandyala gram-49might beat tributed to the difference in their genetic makeup (Indhu Bala Sethi et al., 2016).

Among the three varieties Nandyala gram-49 recorded the highest grain yield but which was statistically on par with Nandayala Senaga-1. Higher grain yield in chickpea varietiesNandyalagram 49 and Nandyala Senaga 1 than Dheera might be ascribed due to higher number of pods per plant and bolder seeds.

The difference in grain yield of chickpea genotypes have also been reported by Nagarajaiah et al., (2005) and Indhu Bala Sethi et al., (2016). These results are also in concurrence with those of Sharma et al., (1988), Dixit et al., (1993) and Kumar et al., (2003). Dheera variety recorded significantly higher haulm yield, which might be ascribed to the taller plants. 


\section{Effect of seed rates}

Varying seed rates of chickpea favourably influenced the plant height and number of pods per plant. Significantly taller plants were recorded at $150 \%$ recommended seed rate. But which was statistically on par with $125 \%$ recommended seed rate. Maximum number of pods per plant was recorded at $125 \%$ recommended seed rate, but which was statistically on par with $150 \%$ recommended seed rate. However 100 grain weight was not significantly affected by different seed rates, because seed weight is a genetic character. Among the three seed rates $150 \%$ recommended seed rate recorded the highest grain yield, but which was statistically on par with $125 \%$ recommended seed rate. This might be due to higher number of pods per plant at $125 \%$ and $150 \%$ recommended seed rate. Similar results were reported by Indhu Bala Sethi et al., (2016). Machado et al., (2003) also reported that grain yield increased when the seeding rate was increased from 17 to 33 seeds $\mathrm{m}^{-2}$. The highest grain yield was observed in chickpea sown with planting density of 28 plant $\mathrm{m}^{-2}$ with respect to the number of pods, number of grains per plant and 100 grain weight at IZU, Iran (KeyvanShamsi, 2010). Haulm yield was not significantly influenced by different seed rates (Table 2-4).

Table.1 Yield parameters and yield of Chickpea as influenced by different varieties and seed rates

\begin{tabular}{|l|c|c|c|c|c|c|}
\hline \multicolumn{1}{|c|}{ Treatment } & $\begin{array}{c}\text { Plant ht. } \\
(\mathbf{c m})\end{array}$ & $\begin{array}{c}\text { No. of } \\
\text { pods / } \\
\text { plant }\end{array}$ & $\begin{array}{c}\text { Test wt. } \\
\text { (g) }\end{array}$ & $\begin{array}{c}\text { Grain } \\
\text { yield } \\
\text { (kg/ha) }\end{array}$ & $\begin{array}{c}\text { Haulm yield } \\
\text { (kg/ha) }\end{array}$ & $\begin{array}{c}\text { Harvest } \\
\text { index (\%) }\end{array}$ \\
\hline NandyalSenaga 1 & 26.6 & 33 & 28.6 & 1097 & 1182 & 48.1 \\
\hline Dheera & 38.5 & 28 & 25.7 & 934 & 1355 & 40.6 \\
\hline Nandyala gram 49 & 28.4 & 37 & 29.8 & 1151 & 1236 & 48.2 \\
\hline SE. m +/- & 0.45 & 0.86 & 0.52 & 20.62 & 24.11 & 0.39 \\
\hline CD at 5\% & 1.8 & 3.3 & 2.0 & 80.9 & 94.7 & 1.5 \\
\hline C. V. (\%) & 4.33 & 7.96 & 5.52 & 5.8 & 5.75 & 2.56 \\
\hline 100\% Rec. seed rate & 28.7 & 29 & 27.2 & 943 & 1165 & 44.7 \\
\hline 125\% Rec. seed rate & 31.2 & 35 & 29.0 & 1104 & 1290 & 45.9 \\
\hline $\mathbf{1 5 0 \% ~ R e c . ~ s e e d ~ r a t e ~}$ & 33.6 & 34 & 27.8 & 1135 & 1319 & 46.3 \\
\hline SE. m=/- & 1.19 & 0.63 & 0.75 & 27.26 & 22.53 & 0.58 \\
\hline CD at 5\% & 3.65 & 2.0 & N.S & 84.0 & NS & N.S \\
\hline C. V. (\%) & 11.41 & 5.86 & 8.04 & 7.7 & 5.37 & 3.82 \\
\hline Interaction (V x S) & N.S & Significant & N.S & Significant & N.S & N.S \\
\hline
\end{tabular}


Table.2 No. of pods / plant of Chickpea as influenced by interaction of different varieties and seed rates

\begin{tabular}{|l|c|c|c|c|}
\hline & $\begin{array}{c}\text { Nandyal } \\
\text { Senaga 1 }\end{array}$ & Dheera & $\begin{array}{c}\text { Nandyala } \\
\text { gram 49 }\end{array}$ & Mean \\
\hline $\mathbf{1 0 0 \%}$ Rec. seed rate & 25 & 26 & 34 & 29 \\
\hline $\mathbf{1 2 5 \%}$ Rec. seed rate & 38 & 28 & 38 & 35 \\
\hline $\mathbf{1 5 0 \%}$ Rec. seed rate & 34 & 30 & 37 & 34 \\
\hline Mean & 33 & 28 & 37 & \\
\hline & SE. m +/- & C.D. at 5\% & & \\
\hline Sub P means at same level Main P & 1.10 & 3.4 & & \\
\hline Sub P means at same level Main P & 0.63 & 2.0 & & \\
\hline
\end{tabular}

Table.3 Seed yield (kg/ha) of Chickpea as influenced by interaction of different varieties and seed rates

\begin{tabular}{|l|c|c|c|c|}
\hline & $\begin{array}{c}\text { Nandyal } \\
\text { Senaga } 1\end{array}$ & Dheera & $\begin{array}{c}\text { Nandyala } \\
\text { gram 49 }\end{array}$ & Mean \\
\hline $\mathbf{1 0 0 \%}$ Rec. seed rate & 1004 & 791 & 1036 & 943 \\
\hline $\mathbf{1 2 5 \%}$ Rec. seed rate & 1182 & 884 & 1247 & 1104 \\
\hline $\mathbf{1 5 0 \%}$ Rec. seed rate & 1105 & 1128 & 1171 & 1135 \\
\hline Mean & 1097 & 934 & 1151 & \\
\hline & SE. m=/- & C.D. at 5\% & & \\
\hline Sub P means at same level Main P & 47.22 & 145.5 & & \\
\hline Sub P means at same level Main P & 43.72 & 134.7 & & \\
\hline
\end{tabular}

Table. 4 Net returns (Rs. ha ${ }^{-1}$ ) as influenced by varieties, seed rates and their interaction

\begin{tabular}{|r|r|r|r|r|}
\hline & Nandyal Senaga 1 & Dheera & Nandyala gram 49 & Mean \\
\hline $\mathbf{1 0 0 \%}$ Rec. seed rate & 11694 & 2256 & 13048 & 8999 \\
\hline $\mathbf{1 2 5 \%}$ Rec. seed rate & 17285 & 4160 & 20119 & 13855 \\
\hline $\mathbf{1 5 0 \%}$ Rec. seed rate & 11881 & 12908 & 14779 & 13189 \\
\hline Mean & 13620 & 6441 & 15982 & \\
\hline
\end{tabular}


Interaction of chickpea varieties and seed rates

Nandyala gram 49 and Nandyala Senaga 1 recorded the highest seed yield at 125\% recommended seed rate. Dheera recorded the highest seed yield at $150 \%$ recommended seed rate. This might be due to the highest number of pods per plant were recorded at $125 \%$ recommended seed rate in Nandyala gram 49 and Nandyala Senaga 1. In Dheera the highest number of pods per plant was recorded at $150 \%$ recommended seed rate. Among all the treatments the highest net returns were recorded with Nandyala gram 49 at $125 \%$ recommended seed rate.

\section{References}

Annual Report 2016-17. Department Agriculture, Cooperation and Farmers Welfare, Ministry of Agriculture and Farmers Welfare, Government of India, Krishi Bhawan, New Delhi.

Dixit, J. P., Pillai, P. V. A. and Namdeo, K. N. 1993. Response of chickpea (Cicer arietinum L.) to planting date and irrigation schedule. Indian Journal of Agronomy 38(1): 121-123.

Fisher, R. A. 1950. Statistical methods for research workers, Oliver and Boyd. Edinburg, London, United Kingdom.

Gan, Y. T., Siddique, K. H. M., Macleod, W. J. and Jayakumar, P. 2006. Management options for minimizing the damage by ascochyta blight (Ascochyta rabiei) in chickpea (Cicer arietinum L.). Field Crop Research 97: 121-143.

IndhuBalaSethi, MeenaSehwag, Parveen Kumar and Mahesh Jajoria 2016. Yield performance of chickpea cultivars as influenced by sowing time and seed rate. The Bioscan 11(1): 407-409.

Jackson, M. L. 1967. Soil chemical analysis Prentice - Hall of India Private Ltd, New Delhi, PP. 498.
Jettner, R. J., Siddique, K. H. M., Loss, S. P. and French, R. J. 1999. Optimum plant density of desi chickpea (Cicer arietinum $L$.) increases with increasing yield potential in South- Western Australia. Australian Journal of Agricultural Research. 50: 1017-1025.

Keyvan Shamshi 2010. Effect of sowing date and row spacing on yield and yield components on Hashem chickpea variety under rainfed condition. African Journal of Biotechnology 9(1): 23-26.

Kumar, M., Singh, R. C., Kumar, R. and Singh, S. 2003. Effect of date of sowing and row spacing on performance of chickpea genotype. Haryana Journal of Agronomy 19(2): 140-141.

Machado, S., Hamphreys, C., Tuck, B., Darnell, T. and Corp, M. 2003.Variety, seeding date, spacing and seeding rate effects on grain yield and grain size of chickpea on Eastern Ortegon. Agric. Exper Station Oregon State Univ. Special Report. Pp. 1047.

Muhr, G. R., Datta, N. P., Sankaranbramoney, H., Lely, V. P. and Donahaue, R. L. 1965. Soil testing in India, USAID, New Delhi, India. Pp. 39-41.

Nagarajaiah, K. M., Palled, Y. B., Patil, B. N. and Khot, A. B. 2005. Response of chickpea varieties to seed rate and time of sowing under late sown conditions in Malaprabha Command area. Karnataka Journal Agricultural Sciences 18(3): 609-612.

Reddy, B.V. S., Reddy, P. S., Bidinger, F. and Blummel, M. 2003. Crop management factors influencing yield and quality of crop residues. Field Crops Research. 84: 57-77.

Regan, K. L., Siddique, K. H. M. and Martin, D. 2003. Response of Kabuli chickpea (Cicer arietinum L.) to sowing rate in Mediteranean type environments of South- Western Australia. Australian Journal of Experimental Agriculture. 
43: 87-97.

Sharma, M. L, Chauhan, Y. S., Bhardwaj, G. S. and Sharma, R. K. 1988. Relative performance of chickpea varieties to sowing dates. Indian Journal of Agronomy 33(4): 452-454.

Silim, S. N. and Saxena, M.C. 1991. Winter sowing in chickpea-A case study. Pages 119-129 in H. C. Harris, P.J.M. Cooper and M. Pala, eds. Soil and crop management for improved water use efficiency in rainfed area. ICARDA, Aleppo, Syria.

Subbaiah, B. V. and Asija, G. L. 1956.A rapid procedure for the estimation of available nitrogen in soils. Current Sci., 25: 259-260.

Walkely, A and Black, C. A. 1934. Estimation of organic carbon by chromic acid titration method. Soil Science. 37: 29-38.

\section{How to cite this article:}

Sujathamma, P. and Venkatesh Babu, D. 2019. Standardization of Seed Rate for Mechanical Sowing of Newly Released Varieties of Chickpea. Int.J.Curr.Microbiol.App.Sci. 8(02): 17191724. doi: https://doi.org/10.20546/ijcmas.2019.802.202 